\title{
A Non-Traditional Approach to a Curriculum for Prisoners In New York State Juan Rivera
}

\section{THE DIRECT RELATIONSHIP}

The need for a non-traditional approach to education in the New York State prison system derives from what a group of innovative prisoners calls the 'direct relationship' between the sixty-two prisons in New York and the specific communities where prisoners come from. A curriculum reflecting the reforms requested by New York's Commissioner of Education are needed, but for prisoners the curriculum must include an additional dimension. It must include a non-traditional, community-specific approach that takes the community into account and links the needs of the community with those of the offender. After all, those needs brought most of the offenders to prison in the first place.

Why a non-traditional approach, and what does it mean? To answer this we must first define a traditional approach. From our perspective this is a curriculum which is Eurocentric, white, and middle-class. It is taught to a variety of ethnic groups on the false assumption that anyone is able to fit into this society. In contrast, a nontraditional curriculum recognizes Latino and Afrocentric perspectives. It acknowledges the poor and the reality that we are not allowed to fit into Eurocentric society. Fundamental differences between cultures must be considered and understood in all curriculum initiatives, since they concern every aspect of our lives.

Why should prisoners in New York demand such a non-traditional curriculum? They want it because it reveals the direct relationship that is, although Blacks and Latinos together represent less than twentyfive percent of the total general population in New York, they comprise 82.3 percent of the State's total prison population, ${ }^{1}$ with the Latino population the fastest growing segment in the State's prison system. Furthermore, the direct relationship reveals that seventy percent or more of the prisoners come from New York City (Correctional Association, New York and New York State Coalition for Criminal Justice, 1990: 7). Perhaps more important it recognizes that eighteen specific assembly districts in New York City contribute seventy percent of the prisoners, which leads to our next question: What is occurring in those eighteen assembly districts that is not occurring in the other 132 districts in New York State?

Juan Rivera (86A3200) is a prisoner and educator at Fishkill Correctional Facility, P.O. Box 1245, Beacon, N.Y. 12508. Anyone who is interested in obtaining more information on this work should contact him at this address. 
There are 'crime generative factors,' commonly known as family breakdown, poor health care, substandard housing, under-education, high unemployment, drugs, discrimination, prison, etc., that are prevalent in those assembly districts and are the root cause of our problems. Without question these 'crime generative factors' are the reasons why such a disproportionate number of Latinos and Blacks are in prison. Consequently, these root causes must be understood from a Latino and Afrocentric perspective.

Our analysis is not a unique one with respect to socio-economic conditions, but it is one that seeks a solution from the perspective of those most affected by the ever-increasing incarceration rate and a recidivism rate which, according to the Department of Correctional Services, was at 39.5 percent in 1988 (1988: 8-9). Since approximately ninety-five percent of the prison population when released return to the communities from which they come, and since four out of ten of these people will return to prison, this suggests that released offenders returning to their communities are contributing to the higher percentage of the overall crime rate in these districts.

\section{TRADITIONAL VERSUS NON-TRADITIONAL}

There is a popular assumption that while people are in prison something is being done to address the problems that caused them to come to prison. However, the traditional methods that are used do not work for the majority of prisoners, who today are either Latino or Black, because the traditional methods do not take into account the institutional failures and 'crime generative factors' that exist in our communities. The traditional methods imply that the fault rests solely with the offenders: that they commit their crimes because there is something wrong with them (i.e., that they are inherently evil). Conversely, the non-traditional approach claims that there are socio-economic conditions, in addition to the individual's behavior, that cause a person to commit a crime. We say that these factors cannot be overlooked and in fact should be addressed by providing a non-traditional course in basic civic and community politics. Instead of rehabilitation, we like to call this an empowerment process which allows individuals to transform themselves from what they were to what they can become. In place of the helplessness poor people often feel, a sense of control over their future is instilled in them and this empowerment works to transform a criminal mentality into a progressive and law-abiding one by permitting the ex-offender insight into failing institutions in their own communities.

In addition, African and Latin American history classes should be established and attached to all educational institutions, including the General Education Diploma (G.E.D) educational program. At the 
Green Haven Correctional Facility we have observed that prisoners who attended both the Black and Latin American history classes acquired a G.E.D. diploma and went on to enroll in the Dutchess or Marist College with greater success than those who did not attend either class. Although we have not conducted an empirical analysis of the success rate of students who take these classes, we believe the classes capture the interest of students and stimulate their learning ability. Moreover, these classes serve to instill a natural sense of self-worth which cannot be inculcated through a Eurocentric approach. For the Italian, Irish, and other Europeans, the Anglo-Saxon model might be a normal and suitable standard of achievement; however, the African descendant needs an African frame of reference and the same is true for the Hispanic.

\section{MODEL CLASSES}

In order to release from prison people who have been educated with a new vision of themselves, and of the purpose and direction their lives should take from that point onwards, we have created two classes which we think can serve as models for other prison education programs and which address the responsibilities we have to ourselves and our communities.

Addressing these responsibilities is essential if we are to survive as individual ethnic groups and simultaneously thrive as American citizens. These classes take into consideration three principal characteristics of the prisoner which the state's traditional approach does not address: (1) the crime generative attitudes of the prisoner and their origins, (2) the ethnic status and identity of the prisoner, and (3) a sense of community. Let us examine these from the perspective of those who have lived in prison.

The first characteristic, the crime generative attitudes of the prisoner, are created by the socio-economic conditions which exist in the community. These are the attitudes which lead one to believe that, "You must make it in this society by being tough and mean, or by any way you can." Thus, a disrespect for the laws of American society arises. This happens when a distinct people experiences segregation, injustice, inferior education, and the force of police as the slave patrols (Williams and Murphy, 1990: 3-5). This happens when people are deprived of community control, political control, and economic independence (i.e. they lack repatriation) (Blauner, 1990: 111).

The longing to fit the traditional European model often leads to selfhatred because we fail to 'fit in' and this places our community members on a collision course with the 'white man's law.' We seek compensation for our failures by acquiring symbols of success, money, and 
material possessions, which for most of us can only be gained illegally and often in the form of ethnic crime. Hence, we develop the attitude that illegal activity is all right.

Ethnicity then is central to the problem of crime, and understanding ethnicity in this way must become part of a prison curriculum. The study of ethnic status and identity helps prisoners to deal with the reality of their ethnic status in American society, which is that of second-class citizens. More positively, it identifies the role of ethnic groups in American history. This develops the positive self-esteem needed to advance past the stereotypes and stigmas created for us by others. An understanding of ethnic status also challenges the feeling of powerlessness which keeps us from doing something about our present conditions.

The final characteristic, the sense of community, must also have a place in prison education programs. Having a sense of community empowers prisoners because it links them with groups in the community and teaches them how their community operates. We learn from an historical perspective about the development of community concepts, including community concepts of social control which take into consideration the impact of crime generative factors on community empowerment movements. All of these factors afford the prisoner insight into how $\mathrm{s} / \mathrm{he}$ fits in the community, thereby instilling in ourselves concern for the community and the people in it. The prisoner learns to see how people are struggling as a community to survive.

The classes are designed to develop a well rounded person with some basic knowledge, ranging from the meaning of ethnocentricity to what is liberation theology. We recommend these classes be scheduled for a period of six months. Throughout the course outside speakers should participate and provide insight to related issues. We also encourage grass-roots groups from the community to assist us in improving what we have developed so far, for we sternly believe that there are no prison problems, only community problems which we bring with us to prison. And since it is the community's survival that is at stake, their input is most essential.

\section{PURGING STAGES}

Equally important is the need to help prisoners deal with negative influences which have been embedded in their personalities. Hence, we advocate self-development purging stages which help to create a new Hispanic or Black person through (1) emotional purging; (2) educational purging; and (3) social purging.

The first purging stage addresses emotions such as racism, sexism, hate, vanity, and desires. We also examine the negative and positive 
practices of machismo. Educational purging attempts to eliminate the effects of mis-education, the result of skewed demographics, all-white American history, and traditional (i.e Eurocentric) learning. Emphasis is placed on re-education by acknowledging our own history and nontraditional knowledge. We find that the social purging stage is the most important part of the process by which we come to understand why we are who we are and how we got that way. It addresses both those aspects of our social perspective that need revamping and changing in our minds and the way we conceptualize our own reality. This is where we begin to breach the stereotypes and stigmas that society creates for us, which are the major restrictive constructs, the subliminal underpinnings of our psycho-social problems.

A theory which supports the purging stage is the labeling perspective. We must be in a position to choose between positive and negative role models, but this cannot be done until we are in a position to identify and understand these role models. For example, C.H. Cooley's (1983) theory the looking glass self' suggests just how important it is to understand the labeling process and its detrimental effects on the individual's self-image and the image of the entire community. The labeling process is executed through the traditional educational system. Both the labels and the labeling process are made to appear real/ natural by the media. We must understand this process and its dangerous effects so we can begin to redefine our own reality and make concerted efforts towards changing conditions in our communities. In this way, we can become a life-giving component instead of an element which destroys those very communities in which we live and die.

\section{CONCLUSION}

We as prisoners are making an honest effort at reconciling ourselves with those communities we helped to destroy. We realize that we harmed not only ourselves but the community as well. With these classes we hope to open prisoners' eyes, to give new meaning to our lives, and to allow us to see ourselves as part of the community.

We do not have all the answers, nor do we pretend to have them. Nevertheless, we have begun something meaningful which can become a turning point in this destructive process taking place today. Also, we realize that much of the community hesitates to accept us, and we understand these feelings. Thus, we have formulated a five-step reconciliation process entailing recognition, responsibility, reconstruction, reconciliation, and redemption. It attempts to bring together the community and prisoners for the purpose of creating non-traditional approaches to the problems of crime and criminal justice. Prisoners must recognize that they have committed wrongs against their communities so that reconciliation with communities can begin and meaning- 
ful working relationships can be developed amongst themselves as participants in the workshops.

Here at the Fishkill Correctional Facility, we are attempting to formulate another class similar to the ones we created at the Green Haven Correctional Facility. We call these model classes the "Conciencia and Resurrection" study groups. Conciencia, in Spanish translates "to be in a state of consciousness." The class attempts to address our problems from a Latinocentric perspective. Likewise, the Resurrection study group instructs from an Afrocentric perspective.

We encourage anyone who is interested and able to assist us in enhancing these classes and our curriculum, and/or anyone who wants more information concerning the classes to contact us in writing. CONCIENCIA!

\section{ENDNOTES}

1. Ethnic distribution of inmates under custody in New York State Correctional Facilities as of June 4, 1990.

\section{REFERENCES}

Blauner, R. 1990. 'The Internal Colonialism,' V.N. Parillo, ed., Strangers To These Shores, Race and Ethnic Relations in the United States, 3d ed. Boston: Houghton Mifflin

Cooley, C.H. 1983. Human Nature and the Social Order. New Brunswick, NJ: Transaction Books

Correctional Association of New York and New YorkState Coalition for Criminal Justice. 1990. 'Underlying Social and Economic Factors.' Imprisoned Generation. New York: Correctional Association of New York (September).

Department of Correctional Services. 1988. 'Increasing Parole Success.' Today, 1(9): 89

Williams, H., and P.V. Murphy. 1990. The Evolving Strategy of Police:A Minority View. Washington, D.C.: The National Institute of Justice, U.S. Department of Justice. 